\title{
Association between gold induced skin rash and remission in patients with rheumatoid arthritis
}

\author{
DAN CASPI, MOSHE TISHLER, AND MICHAEL YARON
}

From the Department of Rheumatology, Ichilov Hospital, Tel Aviv Medical Center, and the Tel Avivon University Sackler Faculty of Medicine, Tel Aviv, Israel

SUMMARY The coincidence of skin eruption and remission induced by gold has not previousl $\tilde{S}_{0}^{\circ}$ been reported. In 50 out of 247 patients with rheumatoid arthritis treated with gold salts (Solganal) between 1977 and 1987 treatment was stopped owing to adverse reactions. Skin rasheş were present in 31 patients, 10 had nephropathy, and nine patients had aphthous stomatitis. Alt 31 patients who developed skin eruption entered a concomitant clinical and laboratory remission ${ }^{\omega}$ The remission satisfied the American Rheumatism Association preliminary criteria and was accompanied by a significant decrease of mean erythrocyte sedimentation rate from 43 (SD 13) to $25(11) \mathrm{mm} / \mathrm{h}$. Disease was exacerbated in 23 patients after three to 60 months. Eight patients ar@ in remission at present, five to 68 months after gold treatment was discontinued. In contrast, nळ亠巾 remission was noticed among the 19 patients with nephropathy or stomatitis.

Gold injections in rheumatoid arthritis are associated with a relatively high rate of side effects. It is our experience that some patients show a considerable therapeutic response to gold at the very moment of skin eruption. Colleagues with whom we shared this observation have had similar experiences. Publications on this topic are few as most reports describe therapeutic or side effects of gold without analysing their mutual interrelationships.

The report of the Empire Rheumatism Council ${ }^{1}$ is the only study we could find that examined the relation between the toxic effects of gold and improvement. This work, however, found a better overall outcome in patients without toxicity, without analysing the various side effects separately.

We report a striking and previously undescribed association between skin eruption and remission induced by gold.

\section{Patients and methods}

Between 1977 and 1987247 patients with definite or classical rheumatoid arthritis were treated with sodium aurothioglucose (Solganal). Their medical and laboratory records were reviewed retrospectively. All 51 patients in whom gold treatment was discon-

Accepted for publication 26 January 1989.

Correspondence to Dr Michael Yaron. Department of Rheumatology, Ichilov Hospital, 6 Weizman Street. Tel Aviv. Israel 64239. tinued owing to side effects were asked to particip in the prospective phase of the study. All but ore who was lost to follow up, are still being followed ups in our outpatient clinic. Drug history (other than gold), a detailed questionnaire about sicca symp. toms, routine haematology and blood biochemistry $\mathbb{D}$ rheumatoid factor (latex), and antinuclear factor determinations (on $\mathrm{HEp}_{2}$ cells) were performed ing all patients.

Side effects were classified into cutaneous (maculopapular, urticarial, or desquamating rash) mucosal (aphthae or stomatitis), renal (proteinuria of more than $500 \mathrm{mg} / 24 \mathrm{~h}$ ), and haematological (leucopenia $<3 \times 10^{9}$ white blood cells $/$, thrombocytopeniz $\left.<100 \times 10^{9} / 1\right)$. Eosinophilia was considered as an absolute count $>0.5 \times 10^{9} / 1$. Toxicity was attributed to gold if it appeared during the course of treatmento was clinically characteristic, and disappeared aftes treatment was stopped. Clinical remission was defined according to the preliminary criteria of the American Rheumatism Association ${ }^{2}$ and included duration of morning stiffness, joint pain, tendernessu and swelling, and erythrocyte sedimentation ratê below $30 \mathrm{~mm} / \mathrm{h}$ for women or $20 \mathrm{~mm} / \mathrm{h}$ for men.

Student's $t$ test was used for statistical analysis.

\section{Results}

Patients were divided into three groups according to the type of gold toxicity: group A-31 patients with 
Table 1 Clinical characteristics of the patients with rheumatoid arthritis with side effects due to gold

\begin{tabular}{llll}
\hline & $\begin{array}{l}\text { Group } A^{*} \\
(n=31)\end{array}$ & $\begin{array}{l}\text { Group } B^{*} \\
(n=10)\end{array}$ & $\begin{array}{l}\text { Group } C^{*} \\
(n=9)\end{array}$ \\
\hline $\begin{array}{l}\text { Age (years) } \dagger \\
\text { M/F ratio }\end{array}$ & $59(11)$ & $63(13)$ & $61(13)$ \\
$\begin{array}{l}\text { Disease duration } \\
\text { (years) } \dagger\end{array}$ & $1 / 4 \cdot 6$ & $1 / 4$ & $1 / 3 \cdot 5$ \\
$\begin{array}{l}\text { No (\%) } \\
\text { RF } \ddagger \text { positive }\end{array}$ & $7 \cdot 9(7 \cdot 6)$ & $9 \cdot 2(8 \cdot 1)$ & $9 \cdot 3(6 \cdot 1)$ \\
$\begin{array}{l}\text { No (\%) with } \\
\text { sicca symptoms }\end{array}$ & $6(19)$ & $3(30)$ & $2(22)$ \\
\hline
\end{tabular}

${ }^{*}$ Group $A=$ patients with skin rashes; group $B=$ patients with gold induced proteinuria; group $\mathrm{C}=$ patients with aphthous stomatitis without skin eruption.

†Values are mean (SD).

$\ddagger \mathbf{R F}=$ rheumatoid factor.

Table 2 Clinical outcome and erythrocyte sedimentation rates at the time of discontinuation of gold owing to side effects

\begin{tabular}{|c|c|c|c|}
\hline & $\begin{array}{l}\text { Group } \\
(n=3 I)\end{array}$ & $\underset{(n=10)}{\text { Group } B \S}$ & $\begin{array}{l}\text { Group } \\
(n=9)\end{array}$ \\
\hline $\begin{array}{l}\text { Cumulative dose } \\
\text { of gold (mg) }\end{array}$ & $406(180)$ & $811(193)^{*}$ & $315(204)$ \\
\hline Number of remissions & 31 & None & None \\
\hline $\begin{array}{l}\text { Duration of remission } \\
\text { (range, months) }\end{array}$ & $3-68$ & None & None \\
\hline $\begin{array}{l}\text { ESR } \ddagger \text { before toxic } \\
\text { reaction }\end{array}$ & $43(13)$ & 48 (14) & 38 (12) \\
\hline $\begin{array}{l}\text { ESR after toxic } \\
\text { reaction }\end{array}$ & $25(11)^{*}$ & 45 (16) & 35 (17) \\
\hline
\end{tabular}

* $\mathrm{p}<0.05$.

†Values are mean (SD).

†ESR = erythrocyte sedimentation rate.

$\S$ For explanation of groups see Table 1 .

skin rashes, four of them with concomitant stomatitis; group B-10 patients with gold induced proteinuria; group $\mathrm{C}$-nine patients with aphthous stomatitis without skin eruption. Table 1 summarises the characteristics of the patients. There were no significant differences among the groups with respect to age, sex, disease duration, the presence of rheumatoid factor, and sicca symptoms.

Table 2 reports the clinical outcome and laboratory results at the time of the discontinuation of gold. All 31 patients who developed gold induced skin rash (group A) entered a concomitant clinical remission accompanied by a significant fall of erythrocyte sedimentation rate. The duration of remission varied greatly among the patients. Exacerbation occurred after an average of 12 months (range 3-60 months). Eight patients are in remission at present, five to
68 months after skin rash occurred. In contrast, none of the patients who suffered from proteinuria $(n=10)$, stomatitis $(n=9)$, or thrombocytopenia ( $n=2$, data not shown) had a clinical remission or a significant fall of erythrocyte sedimentation rate. Skin and mucosal lesions occurred earlier than gold induced nephropathy $(\mathrm{p}<0 \cdot 05)$. Eosinophilia (range $\left.0 \cdot 6-2 \cdot 1 \times 10^{9} / 1\right)$ preceding gold toxicity was noticed in four patients with skin eruption, but in none of the 19 patients of groups $B$ and $C$.

Treatment of the skin rash required prednisone (dose range 10-20 mg/day) in four patients for a period of one to four weeks. Five patients received a single injection of corticotrophin. One patient who was receiving prednisone $10 \mathrm{mg} /$ day before the start of gold treatment continued with the same regimen at the time of skin eruption and during the following remission.

During the remission eight patients did not require any drugs, 10 patients used analgesics sporadically, while only $13 / 31$ patients required nonsteroidal anti-inflammatory drugs.

A history of allergy to drugs other than gold was present in five of the 31 patients of group $\mathrm{A}$, in none of the patients who developed gold nephrotoxicity, and in one patient with stomatitis.

\section{Discussion}

When designing the present study we expected to discover a few patients in whom rash and response to gold coincided. On collecting the data we were surprised by the complete overlap between the two phenomena. All 31 patients who stopped gold thioglucose because of skin rash presented concomitant remissions of their disease, lasting five to 68 months and accompanied by a fall of erythrocyte sedimentation rate. In contrast, none of the patients with other gold induced side effects presented a similar response.

Although gold is the classical second line drug in rheumatoid arthritis, many facets of its activity remain obscure. The efficacy of gold was reported by the Empire Rheumatism Council in $1961,{ }^{3}$ and by subsequent studies. ${ }^{4-7}$ Gold induced toxicity, most commonly mucocutaneous, has also been extensively reported. ${ }^{38}$ No means of predicting the beneficial outcome of gold treatment exists, though HLA-DR2 has generally been found to be associated with a better prognosis. ${ }^{9}$ Side effects have been associated with histocompatibility markers; renal and bone marrow toxicity were found to be related to HLAB8 and DR3 ${ }^{10-12} \mathrm{~A}$ association between mucocutaneous side effects and HLA-B35 has been reported by our group..$^{1314}$ 
The correlation between toxicity and benefit of gold has not been previously described. The only work designed for the study of this aspect is the 1961 - Empire Rheumatism Council subcommittee report 'The relation of toxic reactions in gold therapy to improvement in rheumatoid arthritis'. 'In their report 31 patients who had toxic reactions were compared with 46 patients without toxicity. Temporary remissions were not reported in this group, and the 31 toxic cases were considered as a whole without analysing the different side effects. Not surprisingly, these patients, devoid of gold (or of any other second line drug), fared worse at 30 months. The authors conclude their report as follows: 'This trial does not confirm the idea previously held by some clinicians that good therapeutic results are usually to be expected where gold salts have produced toxic effects'.

Further understanding of the immunological and clinical events occurring during chrysotherapy may explain the coincidence of skin rash and remission induced by gold and find the golden mean between the two.

\section{References}

1 Report of the research sub-committee of the Empire Rheumatism Council. Relation of toxic reactions in gold therapy to improvement in rheumatoid arthritis. Ann Rheum Dis 1961: 20: 335-40.

2 Pinals R S, Masi A T, Larsen R A and the subcommittee for criteria of remission in RA of the ARA diagnostic and therapeutic criteria committec. Preliminary criteria for clinical remission in rheumatoid arthritis. Arthritis Rheum 1981; 24: 1308-15.
3 The research sub-committec of the Empire Rheumatis Council. Gold therapy in rheumatoid arthritis. Final report of multicentre controlled trial. Ann Rheum Dis 1961: 20: 315-33.

4 The cooperating clinics committec of the American Rheumatis Association. A controlled trial of gold salt therapy in rheumatoid arthritis. Arthritis Rheum 1973; 16: 353-8.

5 Sigler J W, Bluhm G B. Duncan H. Sharp J T. Ensign D (을 McCrum W R. Gold salts in the treatment of rheumatoigs arthritis. Ann Intern Med 1974: 80: 21-6.

6 Kean W F. Anastassiades T P. Long term chrysotherapo Arthritis Rheum 1979; 22: 495-501.

7 Lockie L M. Smith D M. Forty seven years experience with gold therapy in 1019 rheumatoid arthritis patients. Semes Arthritis Rheum 1985: 14: 238-46.

8 Sambrook P N. Browne C D. Champion G D. Day R $\vec{\omega}$ Vallance J B, Warwick N. Terminations of treatment with gof sodium thiomalate in rheumatoid arthritis. J Rheumatol 1982: 932-4

9 Griffin A J. Wooley P. Panayi G S. HLA-DR antigens and disease expression in rheumatoid arthritis. Ann Rheum Dio 1984; 43: 218-21

10 Panayi G S. Wooley P. Bachelor J R. Genetic basis rheumatoid disease: HLA antigens, disease manifestations and toxic reactions to drugs. $\mathrm{Br}$ Med J 1978; ii: 1326-8.

11 Scherak O, Smolen J S, Mayr W R, Mayrhofer F, Kolarz G. Thumb N J. HLA antigens and toxicity to gold and penicillaminf in rheumatoid arthritis. J Rheumatol 1984; 11: 610-4.

12 Perrier P. Faffoux C. Thomas Ph, et al. HLA antigens and tox reactions to sodium aurothiopropanol sulphonate and D-pen cillamine in patients with rheumatoid arthritis. Ann Rheum $D_{\mathbb{\Phi}}$ 1985: 44: $621-4$.

13 Tishler M. Caspi D, Gazit E. Yaron M. Association of $\& \overrightarrow{B A O}$ B35 with mucocutaneous lesions in Isracli patients with rhe atoid arthritis receiving gold treatment. Ann Rheum Dis 47: $215-7$

14 Ferraccioli G, Peri F. Nervetti A. Ambanelli U, Savi Toxicity due to remission inducing drugs in rheumatoid arthritis Association with HLA-B35 and Cw4 antigen. J Rheumat 1986; 13: 65-8 